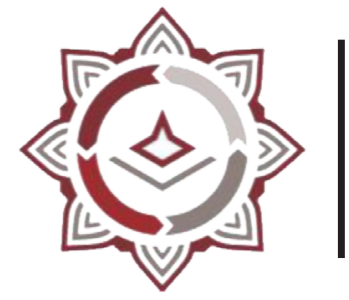

BISNIS: Jurnal Bisnis dan Manajemen Islam

P-ISSN: 2442-3718, E-ISSN: 2477-5533

Volume 9, Nomor 2, Desember 2021 (PP : 345-356)

https://journal.iainkudus.ac.id/index.php/Bisnis/index

http://dx.doi.org/10.21043/bisnis.v9i2.13477

\title{
The Impact of Online Consumer Reviews, E-Service Quality, and Content Marketing on Purchasing Decisions on the Shopee Seller Marketplace, with Islamic Business Ethics as a Moderation Variable
}

\author{
Kharis Fadlullah Hana ${ }^{1}$, Ajeng Rizki Miranti ${ }^{2}$ \\ Institut Agama Islam Negeri Kudus ${ }^{12}$ \\ kharis@iainkudus.ac.id ${ }^{1}$,ajengrizkimiranti013@gmail.com²
}

\begin{abstract}
Today, there is a lot of interest in Indonesian spending on the market; in 2021, overall Indonesian expenditure on the market climbed by $26 \%$. Shopee is an Indonesian marketplace app with 93,440,300 monthly users. Sellers in the Shopee marketplace, on the other hand, are still learning how to effectively handle the platform. As a result, the goal of this research is to see if OCR (Online Consumer Review), E-Service Quality, and Content Marketing influence purchasing decisions, and if so, whether implementing OCR, E-Service Quality, and Content Marketing with Islamic business ethics strengthens or weakens the influence of purchasing decisions. The quantitative technique was employed in this investigation. Students from IAIN Kudus, UMK, and UMKU who utilize the shopee marketplace are the focus of this study. Because the population in this study was unlimited, researchers utilized the lemeshow method to determine the sample size and acquired 96 research samples. This study employs nonprobability sampling methods using purposive sampling. The data gathering approach is done through disseminating questionnaires. SPSS version 2.3 is used to process the data obtained. Validity tests, reliability tests, statistical tests, and traditional assumption tests are all used in data analysis techniques. The findings of this study revealed that online consumer reviews, e-service quality, and content marketing all influenced purchase decisions on shopee seller marketplaces and MRA tests, indicating that Islamic business ethics is a pure moderator variable that has a positive impact on online consumer reviews, e-service quality, and content marketing.
\end{abstract}

Keywords: Online Consumer Review, E- Service Quality, Content Marketing, Islamic Business Ethics and Purchasing Decisions. 


\section{INTRODUCTION}

Today, the development of the internet in Indonesia has increased significantly. As many as 175.2 million Indonesians have used the internet. (Haryanto, 2020) With the development of the internet, entrepreneurs develop electronic commerce innovation, or commonly called e-commerce. E-commerce itself is an online marketplace that conducts business activities to improve the quality of service to consumers. (Yustiani \& Yunanto, 2017: 43) One of the areas of e-commerce that is now much in demand is the marketplace. The concept of a marketplace such as the electronic market, which conducts buying and selling activities, with various select stores in it. (Yustiani \& Yunanto, 2017: 46). One of the marketplaces in Indonesia is shopee. Shopee first launched in December 2015. Unlike other marketplaces, shopee first launched a mobile-based application, with the goal of this shopee application is easier to reach, and easier to use.

Table 1.2 Monthly Visitors Marketplace

\begin{tabular}{cllcccl}
\hline No & Online Store & $\begin{array}{c}\text { Monthly Visitor } \\
\text { Numbers }\end{array}$ & $\begin{array}{c}\text { Rangking } \\
\text { Playstore }\end{array}$ & Twitter & Instagram & Facebook \\
\hline 1. & Shopee & 93.440 .300 & 1 & 320800 & 4851200 & 17841400 \\
\hline 2. & Tokopedia & 86.103 .300 & 3 & 445100 & 1780500 & 6377800 \\
\hline 3. & Bukalapak & 35.288 .100 & 4 & 188600 & 1060900 & 2482800 \\
\hline 4. & Lazada & 22.021 .800 & 2 & 391800 & 2014000 & 29880700 \\
\hline 5. & Blibli & 18.307 .500 & 6 & 501600 & 1225600 & 8591600 \\
\hline 6. & JDID & 9.301 .000 & 7 & 30900 & 476300 & 763200 \\
\hline 7. & Orami & 4.176 .300 & 25 & 6000 & $\mathrm{n} / \mathrm{a}$ & 354400 \\
\hline 8. & Bhineka & 3.804 .800 & 21 & 69400 & 41400 & 1053200 \\
\hline 9. & Zalora & 2.334 .400 & 8 & $\mathrm{n} / \mathrm{a}$ & 557200 & 7827800 \\
\hline 10. & Matahari & 2.197 .200 & $\mathrm{n} / \mathrm{a}$ & 96200 & 140000 & 1599100 \\
\hline
\end{tabular}

(source:iprice.co.id)

Based on the data above, it can be seen that shopee is the marketplace with the most total visitors, which is 93,440,300 people. According to (Nurcholis Maarif, 2020) $63 \%$ of shopee visitors are visitors from the millennial group. Millennials are those between the ages of 25-40 years (Ardina, 2020). Millennials, of course, have several things that can influence their purchasing decisions in the shopee marketplace. A purchasing decision is the stage at which a person will buy or not the item or product he wants. (Rahayu \& Edward, 2014: 7) Unfortunately, shopee sellers or floaters who sell on shopee, do not know what are the factors that influence the 
purchasing decision of the millennial generation. This is certainly a loss for sellers because they cannot analyze their target market behavior properly. According to (Melati, 2020: 887) one that influences purchasing decisions when shopping on the marketplace is the Online Consumer Review Online Consumer Review or customer assessment of a product, or an assessment of the service that the seller provides. In addition, according to (NASIR, 2016: 15) e-service quality is also an important factor in purchasing decisions, and according to (Hastuti, n.d.: 296) content marketing or content-based marketing, is also a matter that influences purchasing decisions. But the results of the study from some of these researchers are different from other researchers. As in the results of the study (Ilmiyah \& Krishernawan, 2020: 41) which actually mentioned that online consumer review, partially had no positive and significant effect on purchasing decisions. Then (Rozi, 2017: 121) also mentioned e-service quality partially positively but not significantly on purchasing decisions. And (Akbar \& Maharani, 2015: 4) mentioned that content marketing has no effect on purchasing decisions. With some differences between researchers with other researchers, and the phenomenon of rampant shopee marketplace users who are not balanced with seller knowledge is what makes researchers interested in researching these variables further. With the research title "Influence of Online Consumer Review (OCR), E- Service Quality and Content Marketing on Consumer Purchasing Decisions on Shopee Seller Marketplace With Islamic Bussines Etics as Moderation Variable". In contrast to previous studies, this time researchers added the islamic bussines ethics variable as a moderation variable. Where Islamic bussines ethict itself is a business behavior that is appropriate and upholds Islamic values by upholding the values of justice, honesty and other Islamic values. (H Fakhry Zamzam, 2020: 3) Based on research Afriyanti Sasnita, Siti usyahidah and Nursyamsu, explained that Islamic business ethics have a positive influence on purchasing decisions. (Sasnita et al., 2020: 86) With this research, researchers make Islamic business ethics or Islamic bussines ethics as a variable of moderation with assumptions, whether islamic bussines ethics will strengthen independent variables (online consumer review, e-service quality and content marketing) or will actually weaken these variables.

\section{LITERATURE REVIEW}

\section{Online Consumer Review}

Online consumer review itself is an assessment of the consumer of the goods he has purchased. (Wahyudi, 2019: 12) By looking at online consumer reviews, 
prospective buyers can see whether the item is worth using and useful for him or not. According to (Zhao et al., 2015: 1346) on his research on the influence of online consumer review on the intensity of hotel bookings. There are several indicators that can measure online consumer review, including the following:

1. Usefulness of online review, refers to the content of previous product consumer reviews.

2. Review expertise, referring to the good of the content of previous comments

3. Timeliness of online review refers to when the review is given.

4. Volume of online review, number of previous comments

5. Comprehensiveness of online review, refers to the authenticity or truth of a given review.

\section{E- service Quality}

E- service quality is a service or service that is done online, and connected through the internet, so that the service or service can provide benefits in the form of information to consumers. (Maulana \& Kurniawati, 2014: 120) e-service quality is an electronic service on a site or application, which serves to provide information about products to consumers, so that consumers can obtain information effectively and efficiently. According to (Ladhari, 2010: 456) to assess the variable e-service quality in online purchases. There are several indicators that can measure e-service quality, including the following:

1. Reability refers to the ability to perform a service well, precisely and accurately.

2. Responsive, refers to the speed of the seller's response in replying to consumer chats in the marketplace.

3. Asssurance refers to the knowledge and ability to engender customer trust

\section{Content Marketing}

Content marketing itself is a marketing strategy by creating content (videos or images) with the aim of informing consumers about the goods to be marketed. There are several indicators that can measure content marketing, including the following. (Yusuf, Ramayani, Heny Hendrayati, 2020: 197)

1. Relevance or presentation of content that suits the needs of consumers.

2. Informative, the presentation of information to increase consumer knowledge.

3. Uniqueness, uniqueness of content marketing 


\section{Islamic Business Ethics}

Islamic business ethics is the application of business by applying Islamic principles in it. (Ghafur, 2018: 66) According to (Jubaedi, 2018: 196), Islamic business ethics can be measured from some of the indicators below.

1. Freedom refers to the freedom of the buyer to review the goods that have been obtained from the seller.

2. Fairness, refers to the buyer who has the right to exchange goods or return goods, if the goods received do not comply with the specifications described by the seller.

3. Honesty, refers to honesty in writing specifications or descriptions.

4. Trust, provide goods in accordance with specifications, and do not ship defective goods.

\section{Purchasing decisions}

Purchasing decisions on the marketplace itself is the decision to buy an item online through the marketplace. According to (P, 2008: 112), there are four indicators that influence purchasing decisions, among others.

1. Stability in a product. What is meant by the stability of a product here is seen in terms of quality. If the product is of good quality, then the consumer will build their trust in the product.

2. Habits in buying a product. The habit referred to here is the act of continuous equal purchase of the product.

3. Make judgments and make recommendations to others.

4. Repurchase.

\section{METHODS}

This type of research is field research and the method used in this research is quantitative methods. The determination of samples in this study uses nonprobality sampling techniques through purposive sampling. Nonprobability sampling is a sampling technique that does not provide the same opportunity for members of the population to be selected to be members of the sample. (Sugiyono, 2016: 83) While Purposive sampling is a way of sampling using certain criteria considerations. (Sugiyono, 2016: 85) This type of research is field research and the method used in 
this research is quantitative methods. The determination of samples in this study uses nonprobality sampling techniques through purposive sampling. Nonprobability sampling is a sampling technique that does not provide the same opportunity for members of the population to be selected to be members of the sample. (Sugiyono, 2016: 83) While Purposive sampling is a way of sampling using certain criteria considerations. (Sugiyono, 2016: 85). The sample criteria in this study are students of Muria Kudus University, Muhammadyah Kudus University and the Holy State Islamic Institute who had bought goods at shopee. The sample of this study was 32 students of Muria Kudus University, 32 students of Muhammadiyah Kudus University and 32 students of the Holy State Islamic Institute. Data collection uses kuesioner analyzed by using MRA to determine the effect of moderating variables on the relationship between independent and dependent variables.

\section{RESULTS}

\section{Descriptive Statistics Table}

\begin{tabular}{|c|c|c|c|c|c|c|c|}
\hline \multicolumn{2}{|c|}{ gender } & \multicolumn{6}{|c|}{ age } \\
\hline Female & Male & $\begin{array}{l}19 \text { years } \\
\text { old }\end{array}$ & $\begin{array}{c}20 \\
\text { years old }\end{array}$ & $\begin{array}{c}21 \\
\text { years old }\end{array}$ & $\begin{array}{c}22 \\
\text { years old }\end{array}$ & $\begin{array}{c}23 \\
\text { years old }\end{array}$ & $\begin{array}{c}24 \\
\text { years old }\end{array}$ \\
\hline 73 & 23 & 10 & 34 & 36 & 11 & 3 & 2 \\
\hline \multicolumn{2}{|c|}{ Religion } & \multicolumn{3}{|c|}{ College } & \multicolumn{3}{|c|}{ number of transactions in shopee } \\
\hline Islam & Kristen & UMK & UMKU & IAIN Kudus & $>5$ & 5 & $<5$ \\
\hline 95 & 1 & 32 & 32 & 32 & 79 & 12 & 5 \\
\hline \multicolumn{8}{|c|}{ goods purchased } \\
\hline Skincare & Makeup & Clothes & $\begin{array}{c}\text { hp } \\
\text { accessories }\end{array}$ & food & bag & Shoes & $\begin{array}{c}\text { kpop } \\
\text { merchandise }\end{array}$ \\
\hline 30 & 25 & 10 & 7 & 5 & 3 & 3 & 2 \\
\hline \multicolumn{8}{|c|}{$\begin{array}{l}\text { Number of transactions each } \\
\text { month }\end{array}$} \\
\hline$>2$ & 2 & $<2$ & & & & & \\
\hline $50 \%$ & $29 \%$ & $21 \%$ & & & & & \\
\hline
\end{tabular}

From the data, it is known that female respondents dominate with a total of 73 respondents, while male respondents as many as 23 respondents. Vulnerable respondents are between 19-24 years old. In this study, 36 respondents aged 21 
years, 34 respondents aged 20 years, 11 respondents aged 22 years, 10 respondents aged 19 years, 3 respondents aged 23 years and 2 respondents aged 24 years. The majority of respondents are 95 respondents. From the data, it is known that female respondents dominate with a total of 73 respondents, while male respondents as many as 23 respondents. Vulnerable respondents are between 19-24 years old. In this study, 36 respondents aged 21 years, 34 respondents aged 20 years, 11 respondents aged 22 years, 10 respondents aged 19 years, 3 respondents aged 23 years and 2 respondents aged 24 years. The majority of respondents are 95 respondents. The other respondent was Christian. There were 96 respondents with 32 respondents who were students from IAIN Kudus, 32 student respondents of Muria Kudus University (UMK) and 32 student respondents of Muhammadiyah Kudus University (UMKU). A total of 79 respondents made transactions at shopee more than 5 times, 12 respondents made transactions at shopee as many as 5 times and as many as 5 respondents only made transactions in shopee under 5 times. The other respondent was Christian. There were 96 respondents with 32 respondents who were students from IAIN Kudus, 32 student respondents of Muria Kudus University (UMK) and 32 student respondents of Muhammadiyah Kudus University (UMKU). A total of 79 respondents made transactions at shopee more than 5 times, 12 respondents made transactions at shopee as many as 5 times and as many as 5 respondents only made transactions in shopee under 5 times. 30 respondents shopped for skincare products at shopee, 25 respondents shopped for makeup products, 10 respondents shopped for clothing products, 7 respondents shopped for mobile phone accessories, 5 respondents shopped for food, 3 respondents shopped for bags, 2 respondents shopped for shoes, and one respondent shopped for kpop merchandise. In the table it is known that $50 \%$ of respondents in this study make transactions more than 2 times a month, while as many as $29 \%$ of respondents make transactions at Shopee as much as 2 times a month and $21 \%$ of respondents make transactions at Shopee as much as 1 time a month.

Respondent Questionnaire Results Table

\begin{tabular}{lccccc}
\hline \multicolumn{1}{c}{ Indikator } & P1 & P2 & P3 & P4 & P5 \\
\hline $\begin{array}{l}\text { Online Consumer } \\
\text { Review }\end{array}$ & 3,15 & 3,09 & 2,97 & 3,07 & 3,07 \\
\hline E- Service Quality & 2,89 & 3,05 & 2,95 & & \\
\hline Content Marketing & 2,98 & 3,14 & 3,03 & & \\
\hline Islamic Business Ethics & 3,05 & 3,14 & 3,07 & 2,91 & \\
\hline
\end{tabular}


The table shows the average of respondents' answers to questions on each indicator. In the table, it can be seen that the indicator with the most average values on the first variable is the content of previous consumer reviews, while in the second variable, the indicator with the most average is responsive, then on the third variable, the indicator whose average value is the most is the second indicator that is informative and on the fourth variable, the indicator that has the most average is the indicator of honesty.

\section{Hypothesis Test Results Table}

\begin{tabular}{|c|c|c|c|c|c|c|c|c|}
\hline \multirow[t]{2}{*}{ Uji Hipotesis } & \multicolumn{2}{|c|}{ Uji t } & \multicolumn{3}{|c|}{ Uji Jenis MRA } & \multicolumn{2}{|c|}{ R square } & \multirow[t]{2}{*}{ Information } \\
\hline & $\mathrm{t}$ & Sig & $\mathrm{X}$ & $\mathrm{X}, \mathrm{Y}$ & Interaksi & I & II & \\
\hline Online Consumer Review & 0,001 & 3,452 & 0.000 & 0.000 & 0.266 & 0,604 & 0,681 & Accepted \\
\hline E- Service Quality & 0,005 & 2,865 & 0.090 & 0.000 & 0.223 & 0,501 & 0,618 & Accepted \\
\hline Content Marketing & 0,005 & 2,854 & 0.000 & 0.000 & 0.937 & 0,548 & 0,639 & Accepted \\
\hline Islamic Business Ethics & 0,008 & 2,721 & & & & & & \\
\hline
\end{tabular}

In the $t$ test, it can be seen that no variable has a calculated $t$ value below 1,290 and a significance level above 0.05 . This suggests that there is a significant individual influence between X1, X2, X3 and X4 on Y. Based on the regression output of the MRA type test on the table, the significance values on the second equation (X, Z) are all smaller than 0.05 , so the islamic busines ethics variable has a significant effect on purchasing decisions. Based on the output of the third regression equation (interaction) obtained the significance values in each regression are $0.266,0.223$ and 0.937 where all values are greater than 0.05 , then the interaction variable has no effect on purchasing decisions. Therefore, the Islamic Business Ethics variable here is a pure variable of moderation between the variables of online consumer review, e-service quality and content marketing to purchasing decisions. The basis of this decision-making is based according to Imam Ghozali, if the regression value of the second equation is significant and the third regression is not significant, then the variable is included in the pure moderator (Ghozali, 2013). In the first model the value of $\mathrm{R}$ square on the online consumer review variable is 0.604 . On the second model it rose to 0.681 . The value of $\mathrm{R}$ Square on the e-service quality variable also rose from 0.501 to 0.618 and the content marketing variable rose from 0.548 to 0.639. From the data it can be concluded that the Islamic Business Ethics variables in this study strengthen the influence of online consumer review, e-service quality and content marketing variables. The basis of this decision-making is based on Wiratna 
Sujarweni, if the second R2 is greater than the first R2 model, then the moderation variable strengthens the influence of independent variables on dependent variables (Sujarweni, 2019).

\section{DISCUSSION}

From this study it can be known that $76 \%$ of shopee marketplace users are women aged 20-24 years. Each shopee user has transacted more than 5 times on the shopee marketplace with a total spend of more than 2 times each month. Beauty products such as skincare, makeup and clothing are products that are much in demand by shopee consumers. From this research it is also known that online consumer review, e-service quality and content marketing, with Islamic business ethics as a moderating variable influence purchasing decisions. In the online consumer review variable, the strongest indicator that influences purchasing decisions is the content indicator of previous consumer reviews. This can be seen from the acquisition of the average value on the results of the questionnaire, which places the indicator in the highest order with a value of 3.27. Riska Permatasari and Nisa Cahya as one of the respondents to this study, gave a value of 4 in the previous review indicator, according to them the previous comments are very important if you want to buy a product on the marketplace, because by looking at the previous comments, then the buyer can ensure the quality of the product. In contrast to Nisa and Riska, Nisrina actually gives a value of 2 in the previous comment indicator, according to him the previous review or comment is not so important to see because she does not trust the comments or judgments of others.

The responsive indicator in e-service quality is the strongest indicator, which can influence purchasing decisions, it can be seen from the acquisition of the average value in the results of the questionnaire, which places the indicator in the highest order with a value of 3.05. Riska Permatasari and Nisa Cahya as one of the respondents to this study, giving a value of 4 on responsive indicators, according to them, responsibility sellers are important when buying goods on the marketplace. According to them, when the seller replies to a message from the buyer, it indicates that the seller marketplace is active, besides that if the seller is responsive then the buyer can easily ask the details of the goods to the seller to ascertain the condition of the goods to be purchased. In contrast to Nisa and Riska, Nisrina actually gives a value of 1 on the responsive comment indicator, because as long as she makes transactions at shopee she does not need to ask for product details by sending a 
message to the seller, she simply sees the details of the product in the photo presented and immediately orders it. In addition, informative indicators are the strongest indicators of content marketing variables, which can influence purchasing decisions, it can be seen from the acquisition of average values in questionnaire results, which places the indicator in the highest order with a value of 3.17. Riska Permatasari and Nisa Cahya as one of the respondents to this study, gave a value of 4 on the content information indicator, according to them commenting on detailed content information is very important if you want to buy a product on the marketplace, because by looking at the content information, it can know the specifications of the product in detail. Unlike Nisa and Riska, Nisrina actually gives a value of 2 on the content information indicator, because according to him the content confirmation may not contain actual information (does not include its shortcomings and only includes the advantages). Then with the existence of Islamic business ethics as a variable moderation, it also strengthens the influence of purchasing decisions. The honesty indicator on the Islamic business ethics variable is the strongest indicator that can influence purchasing decisions. Of all these explanations, it can be used as a reference for sellers in starting to sell on the marketplace. New sellers can start selling by selling beauty products, because these products are the products with the highest interest in the shopee marketplace. In addition, sellers can also improve the quality of service such as delivery speed, speed and accuracy of replying to messages and more informative in order to get good comments from previous buyers, because previous comments are the most important thing, which can influence purchasing decisions. Shopee marketplace sellers can also improve the quality of content marketing such as photos or product videos, and provide honest descriptions and details so that consumers are more interested in buying products sold.

\section{CONCLUSION}

Online consumer review with Islamic Business Ethics as a moderating variable has a significant positive effect on purchasing decisions on shopee seller marketplace. E- Service Quality with Islamic business ethics as a moderating variable has a significant positive effect on purchasing decisions on seller marketplace shopee. Content marketing with Islamic business ethics as a moderating variable has a significant positive effect on purchasing decisions on shopee seller marketplaces. 


\section{REFERENCES}

Akbar, A. F., \& Maharani, N. (2015). Pengaruh Content Marketing terhadap Minat Beli Konsumen pada Jasa Kreatif Yours Bandung Effect of Content Marketing on Buying Interest Consumers at Yours Bandung Creative Services. Prosiding Manajemen, Content Marketing, 2015-2018.

Anggraini, C. A., Perbawasari, S., \& Budiana, H. R. (2018). Cyberbranding Sebagai Upaya Membangun Brand Awareness Shopee Indonesia. Commed: Jurnal Komunikasi Dan Media, 2(2), 72. https://doi.org/10.33884/commed.v2i2.471

Ardina, I. (2020). Rentang Usia Generasi Milenial diperbarui. Beritatagar.

Azhari Akmal Taringan. (2016). Dasar Dasar Etika Bisnis Islam. In FEBI Pers Uinsu.

Ghafur, A. (2018). Etika Bisnis dalam Perspektif Islam. Iqtishodiyah : Jurnal Ekonomi Dan Bisnis Islam, 4(1), 63-74. https://doi.org/10.36835/iqtishodiyah.v4i1.74

H Fakhry Zamzam, H. A. (2020). Etika Bisnis Islam Seni Berbisnis Keberkahan. Deepublish.

Haryanto, A. T. (2020). Riset: Ada 175,2 Juta Pengguna Internet di Indonesia. DetikInet.

Hastuti, I. K. (n.d.). Pengaruh Faktor-Faktor Fungsional, Psikologi Dan Konten Terhadap Keputusan Pembelian Produk E-Commerce Website Groupon. Jurnal MIX, Volume III(No. 3), 296.

Ilmiyah, K., \& Krishernawan, I. (2020). Pengaruh Ulasan Produk, Kemudahan, Kepercayaan, Dan Harga Terhadap Keputusan Pembelian Pada Marketplace Shopee Di Mojokerto. Maker: Jurnal Manajemen, 6(May), 25.

Imam Ghozali. (2013). Aplikasi Analisis Multivariate Dengan Program IBM SPSS 21 Update PLS Regresi (7th ed.). Badan Penerbit Universitas Diponegoro.

Jubaedi, J. (2018). Implementasi Etika Bisnis Islam (studi Kasus Pada Mahasiswa Ekonomi Syariah Angkatan 2014 Fakultas Agama Islam Universitas Ibn Khaldun Bogor). Eklektik: Jurnal Pendidikan Ekonomi Dan Kewirausahaan, 1(1), 11. https://doi.org/10.24014/ekl.v1i1.4897

Ladhari, R. (2010). Developing e-service quality scales: A literature review. Journal of Retailing and Consumer Services, 17(6), 465. https://doi.org/10.1016/j. jretconser.2010.06.003

Maulana, R., \& Kurniawati, K. (2014). ( Studi Kasus Pada Website Koren Denim ). 13(2), 120.

Melati, R. S. (2020). Pengaruh Harga Dan Online Consumer Review Terhadap Keputusan Pembelian Case Handphone Pada Marketplace Shopee ( Studi Pada Mahasiswa Surabaya ). 8(2). 
NASIR, M. (2016). Pengaruh E-Service Quality Dan Diskon Terhadap Minat Beli Pada Situs Online Di Website Zalora.Co.Id Di Surabaya. Jurnal Pendidikan Tata Niaga (JPTN), 1(1), 15-18.

Nurcholis Maarif. (2020). Shopee Jadi e-Commerce Terpopuler di IndonesiaNo Title. Selasa, 17 Mar.

P, K. (2008). Manajemen Pemasaran (10th ed.). PT Prebalindo.

Rahayu, P., \& Edward, M. (2014). Pengaruh Word Of Mouth Terhadap Keputusan Pembelian Konsumen Produk Smartfren Andromax (Studi Pada Mahasiswa Kampus Ketintang Universitas Negeri Surabaya). Universitas Negeri Surabaya, 1(1), 1-16.

Rozi, imam fakhrur. (2017). Dimensi E-Service Quality. Pendidikan Tata Niaga, 01(01), 118-122.

Sasnita, A., Musyahidah, S., \& Nursyamsu, N. (2020). Pengaruh Etika Bisnis Islam Terhadap Keputusan Pembelian Busana Muslimah Mahasiswi Jurusan Ekonomi Syariah IAIN Palu. Jurnal Ilmu Ekonomi Dan Bisnis Islam, 1(2), 70-88. https:// doi.org/10.24239/jiebi.v1i2.12.70-88

Sugiyono. (2016). Metode Penelitian Kuantitatif, KKualitatif dan R\&D. Alfabeta.

V. Wiratna Sujarweni. (2019). Spss Untuk Penelitian. Pustaka Baru Press.

Wahyudi, T. (2019). Pengaruh Online Customer Review Dan Online Customer Rating Terhadap Kepercayaan Konsumen Remaja Kota Mataram Pada Pembelian Produk Fashion Shopee Online Shop. Jurnal Riset Manajemen, 19(1), 1. https:// doi.org/10.29303/jrm.v19i1.33

Yaksan Hamzah dan Hamzah Hafield. (2014). Etika Bisnis Islam. Kretakupa Print.

Yustiani, R., \& Yunanto, R. (2017). Peran Marketplace Sebagai Alternatif Bisnis Di Era Teknologi Informasi. Komputa : Jurnal Ilmiah Komputer Dan Informatika, 6(2), 43-48. https://doi.org/10.34010/komputa.v6i2.2476

Yusuf, Ramayani, Heny Hendrayati, L. A. W. (2020). Pengaruh Konten Pemasaran Shopee Terhadap Keputusan Pembelian Pelanggan. Jurnal Manajemen Pendidikan Dan Ilmu Sosial, Volume 1(Issue 2), 506. https://doi.org/ DOI:10.38035/JMPIS

Zhao, X. (Roy), Wang, L., Guo, X., \& Law, R. (2015). The influence of online reviews to online hotel booking intentions. International Journal of Contemporary Hospitality Management, 27(6), 1346. https://doi.org/10.1108/ IJCHM-12-2013-0542 